\title{
APPLICATION OF STAD COOPERATIVE LEARNING MODEL TO INCREASE STUDENTS' LEARNING OUTCOMES IN SOCIAL SCIENCE SUBJECT
}

\author{
Emi $^{1}$
}

${ }^{1}$ State Elementary School Teacher 15 of Cakranegara, Mataram, Indonesia

\section{Article Info}

Article history:

Received: 31-07-2021

Revised: 11-12-2021

Published: 31-01-2022

\section{Keywords:}

Cooperative learning

STAD

Learning outcomes

ABSTRACT

This study aims to improve social studies learning outcomes for the fifth-grade students of SDN 15 Cakranegara in the 2018-2019 school year, totaling 28 people, consisting of 12 boys and 16 girls. The research method used is: Cooperative Learning Model Type Student Team Achievement Division (STAD) with data collection techniques in the form of observation and evaluation tests, then analyzed qualitatively by comparing the success rates between cycles. The results of this study indicate an increase in the number of students who complete learning or get a score of 70 , namely 22 students in the first cycle to 25 students in the second cycle. An increase also occurred in the average value of the evaluation test given after the learning process was over, namely: 75 in the first cycle, to 83 in the second cycle. While the percentage of student learning completeness in each cycle, which is $79 \%$ in the first cycle, increased to $89 \%$ in the second cycle. In addition, the application of this method can also increase the activities of teachers and students which increase from cycle I to cycle II. This is evidenced by the percentage of teacher activity which increased from $75 \%$ in the first cycle to $87 \%$ in the second cycle. Increased student activity is indicated by $65 \%$ in the first cycle, to $81 \%$ in the second cycle. The cooperative learning model of the Student Teams Achievement Division (STAD) type can improve the social studies learning achievement of fifth graders at SDN 15 Cakranegara for the 2018-2019 school year.
\end{abstract}

This is an open access article under the CC BY-SA license.

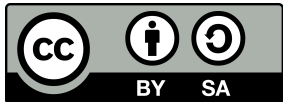

\section{Corresponding Author:}

Emi,

State Elementary School Teacher 15 of Cakranegara, Mataram

J1. Ade Irma Suryani No.65, Karang Taliwang, Cakranegara, Kota Mataram, Indonesia

Email: emialice08@gmail.com

\section{INTRODUCTION}

Education can be interpreted as a conscious effort carried out with the aim of improving the quality of humans, both as individual beings and social beings. Quality humans are expected to be able to understand science in certain fields, be able to reason, and think critically in solving problems to deal with problems, both for themselves and in socializing with other humans. So, in the end, they are able to face the era of globalization which is increasingly competitive and full of the development of Science and Technology.

To create quality human beings, the educational process should have quality. The quality of education can be seen from two things, namely: the quality of processes and products. A quality education process can be seen from the implementation of effective and efficient learning by involving all components of education, 
such as teaching objectives, teachers and students, lesson materials, teaching and learning strategies or methods, learning tools and resources and evaluation. If all these components can be managed properly, then the implementation of learning will be effective and efficient. Meanwhile, the quality of educational products can be seen from the academic achievements of students. If the academic achievement shown is above the specified standard, the educational process can be said to be of high quality. Quality education, both products and outcomes, can support the achievement of educational goals. In the process of quality education, students who study are expected to experience changes both in the fields of knowledge, understanding, skills, values and attitudes as well as their academic achievements. This is in accordance with the objectives of national education in the Republic of Indonesia Law No. 2 of 1989 which states that: National education aims to educate the nation's life and develop Indonesian people as a whole, namely humans who believe and fear God Almighty and have noble character, have knowledge and skills, physical and spiritual health, a strong and independent personality, and a sense of social responsibility and responsibility. Nationality. In reality, not all educational processes can be said to be of high quality. The teaching and learning process in the classroom often experiences problems. These problems can come from the students themselves, the teacher, the field of study being taught, or the infrastructure that supports learning.

Based on the results of initial observations on learning achievement in class V of SDN 15 Cakranegara in the 2018-2019 school year, the following facts were found: (1) In giving material, teachers often emphasize learning the lecture method, so it is too theoretical. In addition, during the teaching and learning process, students are less active in it. This is indicated by the student's response during the learning process. Only students with above average abilities can be actively involved in learning. (2) Many learning materials are narrative and descriptive or rote, especially in social studies subjects. (3) The average value of students' daily tests is still low, especially in social studies subjects which are lower than other subjects. The data in the form of scores obtained by students from observations are as follows: from student score data, with a total of 21 students, only 10 students scored above 74 or $47.62 \%$ on assignments. Students who scored below 74 were 11 students or $52.38 \%$. On the daily test scores, only 8 students scored above 74 or $38.10 \%$. Students who scored below 74 were 13 students or $61.90 \%$. In mid-semester scores, only 14 students scored above 74 or $66.66 \%$. Students who scored below 74 were 7 students or $33.34 \%$. Thus the learning objectives are not as expected.

From the facts above, it can be seen that the level of student achievement is still lacking, especially in social studies subjects. This shows that there are difficulties for students in studying social studies. Based on these problems, it is necessary to apply an appropriate learning model and is expected to activate students in learning. The use of the right learning model will also determine the effectiveness and efficiency of learning. One of the learning approaches that can make learning active, fun and meaningful is cooperative learning. Where in cooperative learning students can learn together, contribute their thoughts and be responsible for the achievement of learning outcomes individually or in groups. One of the cooperative learning models that can be used is the Student Team Achievement Division (STAD) type of cooperative learning. Cooperative Learning Type Student Team Achievement Division (STAD) according to Slavin is a cooperative learning technique that emphasizes the existence of activities and interactions between students to motivate each other and help each other in mastering the subject matter to achieve maximum achievement (Prastya, 2017; Rahmah, Fakhriyah, \& Fardani, 2020; Sumilat \& Matutu, 2021; Wicaksono \& Bariska, 2018; Winaastari, Yudiana, \& Kusmariyatni, 2020; Zahro, Degeng, \& Mudiono, 2018).

By implementing STAD type cooperative learning, it is possible to increase student activity, cooperation, and motivation in the implementation of learning, which is later expected to improve student learning outcomes, especially social studies lessons. Improving learning outcomes fosters quality education. Based on this thought, it is necessary and important to carry out classroom action research regarding the Application of the Student Team Achievement Division (STAD) Cooperative Learning Model to Improve Social Studies Learning Outcomes for Class V Students at SDN 15 Cakranegara for the 2018-2019 Academic Year. Based on the description of the background above, the formulation of the problem in this study is: How can the application of cooperative learning type Student Team Achievement Division (STAD) improve social studies learning outcomes for fifth grade students at SDN 15 Cakranegara in 2018/2019.

\section{RESEARCH METHOD}

This research is a Classroom Action Research. This Classroom Action Research (CAR) was conducted to improve the quality of learning (Arikunto, 2012). Through this CAR, it is hoped that the quality of 
students' social studies learning outcomes can increase (Fatimah, 2021; Jufri, 2010; Nurdin, 2016; Widayati, 2014). This Classroom Action Research is collaborative and reflective. That is, there is cooperation between several people as well as improvements to overcome problems. This research involves collaboration between two parties, namely researchers (observers) and teachers/learning implementer. This Classroom Action Research (CAR) was conducted in class V of SDN 15 Cakranegara in semester 2 of the 2018-2019 academic year. The research subjects in this CAR are all fifth grade students at SDN 15 Cakranegara.

This research is said to be successful if (1) There was an increase in teacher activity and student learning activities after being taught by applying the STAD type cooperative learning model. This learning activity is said to increase if there is an increase in the average score from the previous cycle and the minimum criteria for student learning activities are in good category. (2) The results of the learning test showed individual learning completeness of 70. (3) The results of the learning test obtained an average grade of 75 and classical learning completeness reached $85 \%$.

\section{RESULT AND DISCUSSION}

In this chapter, data from research that has been carried out in the form of actions or processes and learning outcomes with the STAD technique cooperative learning model will be presented to improve social studies learning outcomes for fifth grade students of SDN 15 Cakranegara. In addition, this chapter will also present the results of reflection on the results of the research and discussion of research results. The data will be presented sequentially according to the order of implementation of each cycle.

\subsection{Results of the Implementation of the Cycle}

\subsubsection{Cycle I}

Learning activities in cycle I were carried out in 1 meeting which was held for 3 x 35 minutes, namely on Monday, March 19, 2019. The material discussed in cycle I was to explain the struggle against Dutch colonialism. The first cycle evaluation was carried out directly in the same meeting. Evaluation is given in the form of multiple choice. Activities in cycle I consist of 4 stages, namely:

1. Planning

At this planning stage, several activities were carried out, including the following:

(a) Make a lesson plan (RPP) cycle I

(b) Prepare student worksheets for cycle I

(c) Prepare material summary

(d) Prepare the process assessment instrument

(e) Prepare the assessment criteria format

(f) Develop a lattice of evaluation questions for cycle I

(g) Arrange the first cycle evaluation questions in the form of multiple choice

(h) Prepare student activity observation sheets for cycle I

(i) Prepare an observation sheet for teacher activities in cycle I

2. Action

The activities carried out at this stage are carrying out teaching and learning activities in class according to the plans that have been prepared in the STAD type cooperative learning implementation plan to improve social studies learning outcomes for fifth grade students.

Learning in cycle I took place in 1 meeting, namely on March 19, 2019. The activities carried out at the meeting were carrying out learning activities according to the lesson plan that had been prepared (Appendix 4). At the beginning of the activity, several teacher activities were carried out, namely the teacher invited students to pray, then filled out the student attendance list, prepared students to learn, and gave apperception by inviting students to sing the song "Maju Tak Gentar" then linking the song with the material to be delivered, after that give children motivation by saying "your children must follow this lesson well because it can be used as a provision for lessons in higher classes.In the core activity, activities were carried out, namely, first, the teacher presented subject matter regarding the struggle against Dutch colonialism by conveying the main material, and indicators to be achieved. Then, to explore students' knowledge, the teacher showed several pictures of heroes which were then guessed by students. The second stage is the group activity stage, where the teacher divides students into 5 groups, each group consisting of 4 people, then the teacher distributes LKPD to each group. 
After the LKPD is accepted, the teacher explains how to do the LKPD. After that, the teacher pays attention to the course of the group discussion and then guides students who have difficulty in between group discussions. After finishing the teacher asked each group representative to present the results of the discussion that had been done and the other groups responded. Then the teacher provides improvements and reinforcements after students finish presenting the results of their discussions. In the next stage, namely the individual test stage, the teacher distributes evaluation sheets to be done individually and when working on students should not help each other, after that it is continued with the stage of calculating scores where the evaluation is checked together. After the scores are collected, the teacher looks at the group with the highest score and then gives an award to the group with the highest score. In the last activity, activities were carried out, namely the teacher gave reflection. After that the teacher guides the students to make conclusions from the subject matter then the teacher closes the lesson.

3. Observation and Evaluation

Student activities during the learning process can be seen from the observation sheets made by the observer. From the results of observing student activities, the following data were obtained:

\begin{tabular}{llc} 
Table & 1. Results of Observation of Student Learning Activities (Cycle I) \\
\hline No. & Indicator & Percentage \\
\hline 1 & Enthusiasm of students in participating in learning activities & $75 \%$ \\
2 & Student interaction with teacher & $58 \%$ \\
3 & Student activities in group work & $38 \%$ \\
4 & Student participation in group presentations & $67 \%$ \\
5 & Participation in the reflection of learning outcomes & $88 \%$ \\
\hline \multicolumn{2}{l}{ The average score of student activities } & $65 \%$ \\
\hline \multicolumn{2}{l}{ Category } & Good Enough \\
\hline
\end{tabular}

From the table of observations of student learning activities in cycle I above, it can be seen that the average score of student learning activities in cycle I is $65 \%$ with a fairly good category.

The teacher's activities during the learning process can be seen from the observation sheet made by the observer. From the results of observations of teacher activities carried out, the data obtained are as follows:

Table 2. Observation Results of Teacher Activities (Cycle I)

\begin{tabular}{llc}
\hline No. & Indicator & Percentage \\
\hline 1 & Lesson planning & $100 \%$ \\
2 & Generating student interest and motivation in learning & $58 \%$ \\
3 & Submission of material to students & $63 \%$ \\
4 & Guiding students in group activities & $75 \%$ \\
5 & Assessing student learning outcomes & $92 \%$ \\
6 & Ending the lesson & $63 \%$ \\
\hline Teacher activity average score & $75 \%$ \\
\hline \multicolumn{2}{l}{ Category } & Good \\
\hline
\end{tabular}

From the table of observations of teacher activities in cycle I above, it can be seen that the average score for teacher activities in cycle I is $75 \%$ with a good category.

Evaluation is carried out at the end of each cycle in the same meeting. The teacher gives evaluation questions in multiple choice. The data from the evaluation of the first cycle can be seen in the following table:

Table 3. Observation Results of Teacher Activities (Cycle I)

\begin{tabular}{lc}
\hline Descriptive Statistics & Percentage (\%) \\
\hline The highest score & 100 \\
Lowest value & 50 \\
Class average & 75 \\
Many students have completed & 22 \\
Percentage of students who completed $(\%)$ & 79 \\
\hline
\end{tabular}

From the Table 3, it can be seen that the average grade obtained in the first cycle was 75 with the lowest score of 50 and the highest score of 100. This indicates that the learning outcomes in this cycle have an 
average value of the average number of students has increased when compared to before the treatment of teaching and learning activities using this STAD cooperative model.

4. Reflection

From the results of observations and evaluations of teacher and student activities during the learning process, it can be seen that there are several learning activities that were successfully carried out by teachers and students during the learning process as follows:

(a) The teacher does apperception by inviting students to sing.

(b) The teacher motivates students before learning is done.

(c) The teacher asks questions with pictures to test students' previous understanding.

(d) The teacher divides the students into groups well.

(e) The teacher guides students in group activities well.

(f) Students listen to the results of group presentations quite well.

(g) The teacher gives individual tests and students are quiet while working on the test.

(h) The teacher gives group awards.

(i) The teacher ends the lesson well.

Meanwhile, the shortcomings found from the results of the study or from the observation sheet include the following:

(a) The teacher does not check the readiness of students before learning is carried out.

(b) There are still some students who do not focus on the material being studied.

(c) The teacher has not given students the opportunity to ask questions.

(d) Students are still shy to ask questions about material that has not been understood.

(e) The teacher does not have a good ability in providing reinforcement to students.

(f) Students have not shown good group work activities such as: trying to express their opinions in groups, helping friends to understand the discussion material) so that discussions are dominated by smart students.

(g) The teacher does not guide students in conveying the results of their group work and concluding the results of the discussion.

(h) Students are still shy and not fluent in conveying the results of group discussions.

(i) Students do not want to express opinions on the results of other groups' percentages.

(j) The teacher is lacking in guiding students to make conclusions in their own language.

Indicators of success which include increasing teacher activity can be seen in cycle I which is categorized as good, while student activities and student learning outcomes cannot be seen in cycle I, so the research is continued in cycle II. In the implementation of the first cycle, there were several shortcomings which indicated that corrective action was needed in the second cycle. The corrective actions that will be carried out in cycle II are:

(a) The teacher will check the readiness of students before learning is done

(b) The teacher will pay attention to students who do not focus on the material being studied

(c) The teacher will provide opportunities for students to ask questions

(d) The teacher will guide students to ask questions about material that has not been understood

(e) The teacher will provide reinforcement to students

(f) Before students work in groups, the teacher needs to explain the instructions as clearly as possible in group work and the assessment pattern used

(g) The teacher will guide students in conveying the results of their group work and conclude the results of the discussion

(h) The teacher provides more guidance to students in each group in conveying the results of group work

(i) The teacher will guide students to express opinions about the results of the other groups' percentages

(j) The teacher will guide students to make conclusions in their own language

\subsubsection{Cycle II}

The implementation in cycle II is almost the same as cycle I, but in cycle II improvements are made based on the results of the reflection of cycle I. Learning activities in cycle II are carried out in 1 meeting which is held for 3times35 minutes. The material discussed in cycle II was to appreciate the role of warrior and community leaders in preparing and defending Indonesian Independence. Cycle II evaluation was also carried out directly in the same meeting. Evaluation is given in the form of multiple choice. Activities in cycle II 
consist of 4 stages, namely:

1. Planning

At this planning stage, several activities were carried out, among others, as follows:

(a) Make a lesson plan (RPP) cycle II

(b) Prepare student worksheets for cycle II

(c) Prepare material summary

(d) Prepare process assessment instruments

(e) Develop a lattice of evaluation questions for cycle II

(f) Prepare evaluation questions for cycle II

(g) Prepare data on the results of the evaluation of cycle II

(h) Prepare student activity observation sheets

(i) Prepare teacher activity observation sheets

2. Action

Cycle II carried out teaching and learning activities in class according to the plan that had been prepared in the lesson plan by applying the STAD type cooperative model to improve social studies learning outcomes for class V students. Cycle II was carried out based on the results of the reflection of cycle I. Activities carried out at this stage were the teacher Ask students to gather in their respective groups. Then at the beginning of the activity, several teacher activities were carried out, namely the teacher asked students to pray, then filled out the student attendance list, prepared students for learning, and gave apperception by inviting students to sing the song "Garuda Pancasila" then linking the song with the material to be delivered. In the core activity, activities were carried out, namely, first, the teacher presented subject matter regarding the struggle against Dutch colonialism by conveying the main material, and indicators to be achieved. Then, to explore students' knowledge, the teacher showed several pictures of heroes which were then guessed by students.

The second stage is the group activity stage, where the teacher distributes LKPD to each group. After the LKPD is accepted, the teacher explains how to do the LKPD. After that the teacher pays attention to the course of the group discussion and then guides students who have difficulty in between group discussions. After finishing the teacher asked each group representative to present the results of the discussion that had been done and the other groups responded. Then the teacher provides improvements and reinforcements after students finish presenting the results of their discussions. In the next stage, namely the individual test stage, the teacher distributes evaluation sheets to be done individually and when working on students should not help each other, after that it is continued with the stage of calculating scores where the evaluation is checked together - together. After the scores are collected, the teacher looks at the group with the highest score and then gives an award to the group with the highest score. In the last activity, activities were carried out, namely the teacher gave reflection. After that the teacher guides students to make conclusions from the subject matter then the teacher closes the lesson.

3. Observation and Evaluation

Student activities during the learning process conducted by the observer in the second cycle. From the results of observing student activities, the following data were obtained:

\begin{tabular}{llc} 
Table & Results of Observation of Student Learning Activities (Cycle II) \\
\hline No. & Indicator & Percentage \\
\hline 1 & Enthusiasm of students in participating in learning activities & $88 \%$ \\
2 & Student interaction with teacher & $83 \%$ \\
3 & Student activities in group work & $69 \%$ \\
4 & Student participation in group presentations & $75 \%$ \\
5 & Participation in the reflection of learning outcomes & $88 \%$ \\
\hline \multicolumn{2}{l}{ The average score of student activities } & $81 \%$ \\
\hline \multicolumn{2}{l}{ Category } & Good \\
\hline
\end{tabular}

From the table of observations of student learning activities in cycle II above, it can be seen that the average score of student learning activities in cycle II is increasing to $81 \%$ in the good category.

As in the first cycle, the teacher's activities during the learning process can be seen from the observation sheet made by the observer. From the table of observations of teacher activities in cycle II above, it can be seen that the average score of teacher activities in cycle II has increased to $87 \%$ with a good category. 
Evaluation is carried out at the end of each cycle in the same meeting. The teacher gives evaluation questions in the form of multiple choice. The data from the evaluation of the second cycle can be seen in the Table 5. From Table 6, it can be seen that the average grade obtained in the second cycle was 83 with the lowest score of 70 and the highest score of 100. This shows that the learning outcomes in this cycle have an average value of the average number of students has increased when compared to cycle I. From the table it can be seen that there are 25 people who have completed their studies with a percentage gain of $89 \%$ because this percentage is greater than $85 \%$, so learning in cycle II is said to be classically complete.

Table 5. Observation Results of Teacher Activities (Cycle II)

\begin{tabular}{llc}
\hline No. & Indicator & Percentage \\
\hline 1 & Lesson planning & $100 \%$ \\
2 & Generating student interest and motivation in learning & $83 \%$ \\
3 & Submission of material to students & $75 \%$ \\
4 & Guiding students in group activities & $83 \%$ \\
5 & Assessing student learning outcomes & $92 \%$ \\
6 & Ending the lesson & $88 \%$ \\
\hline Teacher activity average score & $87 \%$ \\
\hline Category & Good \\
\hline
\end{tabular}

Table 6. Results of Cycle II Evaluation

\begin{tabular}{lc}
\hline Descriptive Statistics & Percentage $(\%)$ \\
\hline The highest score & 100 \\
Lowest value & 50 \\
Class average & 83 \\
Many students have completed & 25 \\
Percentage of students who completed $(\%)$ & 89 \\
\hline
\end{tabular}

\section{Reflection}

Based on the results of the research at the observation stage, all learning indicators have appeared, including:

(a) The teacher checks the students' readiness before learning is done

(b) The teacher pays attention to all students to focus on the material being studied

(c) The teacher provides opportunities for students to ask and provide questions according to the material provided

(d) The teacher guides the students to dare to ask questions

(e) The teacher gives reinforcement to students well

(f) Students actively play a role in their groups, learn and work in groups, students exchange ideas in discussions

(g) The teacher guides students in group activities that reflect the application of the STAD-type cooperative model

(h) The teacher guides the students to convey the results of the group discussion

(i) Students dare to express opinions on the results of other groups' presentations

(j) Students are able to conclude their own learning outcomes using their own language

From the results of the evaluation in cycle II, it can be said that classical learning completeness has been achieved, namely $89 \%$ so that learning for the next cycle is not continued, because from the results of research conducted in these two cycles, there is an increase in student learning outcomes.

\subsection{Discussion}

This classroom action research was conducted as an effort to improve social studies learning outcomes for fifth grade students of SDN 15 Cakranegara by applying the STAD type cooperative model, this research was conducted in 2 cycles. Based on the observations made by the observer and the data processing carried out by the researcher, the data obtained from the comparison of teacher activities, student activities and student learning outcomes / mastery learning. The discussion for teacher activities, student activities and student learning outcomes that become an assessment of the success of this research.

From the table above, it can be seen that in the first cycle, classical learning completeness has not been achieved, where the percentage of students who have completed their studies is $79 \%$ and the average score is 
75. From the results of the first cycle evaluation there is an increase in the average value of learning outcomes. students from before this treatment was carried out but the overall percentage of completeness had not reached $85 \%$, this happened because there were visible weaknesses in both student and teacher activities, especially in the aspect of generating student interest and motivation as well as in group activities that had not reflects the application of the STAD type cooperative model which certainly affects student learning outcomes. Students still need adjustments to be able to mingle, learn, cooperate and work in groups well so that smart students do not dominate the activities of this group. To overcome these weaknesses, corrective actions were taken in the second cycle based on the deficiencies that emerged in the first cycle so that in the second cycle the percentage of students who completed their studies was $89 \%$ with an average acquisition of 83 learning outcomes. This percentage of completeness indicates that the achievement of classical learning completeness is at least $85 \%$ of students who complete their studies. With the achievement of completeness in cycle II, the research was not continued to the next cycle.

The increase in student activity and teacher activity and the increase in student learning outcomes is in accordance with the opinion expressed by Slavin (in Isjoni, 2007: 51) that STAD type cooperative learning is one of the cooperative learning techniques that emphasizes the activity and interaction between students to motivate each other and help each other in mastering the subject matter to achieve maximum performance.

From the observations, it is known that STAD cooperative learning in social studies learning can improve a more lively learning atmosphere because all activities are dominated by students, minimize teacher activities in class and teachers act as mediators and facilitators. Students are also trained to be brave in expressing their opinions, dare to ask questions which may be very difficult to develop this ability. In addition, students are trained to socialize in their study groups, foster good cooperation in helping friends who have learning difficulties. Sometimes students find it easier to digest the subject matter presented by their peers. Provide reinforcement to students that there are no stupid students if they want to try in learning, have the same opportunities as other smart students in achieving achievements. The results of this study are in accordance with the opinion of Anita Lie in her book Cooperative Learning (2002: 69) which says that: Peer teaching is effective in boosting student achievement than teacher teaching.

Students' enthusiasm for learning social studies increases at each meeting, there is interaction and collaboration between students with one another in study groups, students' understanding of learning materials is not used as an arena for fear of competing with their friends because they will jointly solve their difficulties in learning without losing their independence in completing questions at the individual evaluation stage later. As a result, the social studies learning outcomes of fifth graders at SDN 15 Cakranegara can be improved by the implementation of the STAD type cooperative model in the class. So the application of the STAD type cooperative model can improve social studies learning outcomes for fifth grade students at SDN 15 Cakranegara.

\section{CONCLUSION}

Based on the whole series of results of classroom action research conducted by the researcher for 2 cycles, as well as the analysis and discussion that has been carried out, there are 3 things that the researcher can conclude, including The application of the Student Team Achievement Division (STAD) type of cooperative learning can improve social studies learning outcomes for fifth graders at SDN 15 Cakranegara in the 2018-2019 academic year. This can be seen based on the increase in the number of students who completed learning from cycle I to cycle II, namely those who got a score of 74. A total of 22 students had completed learning in cycle I, and experienced an increase in the number in cycle II to 25 people. From the number of students who completed the study, it is also known that the percentage of student learning completeness increased from cycle I with $79 \%$, to cycle II with $89 \%$. This increase in results can also be seen from the average score of students which increases in each cycle, from a score of 75 in the first cycle to a value of 83 in the second cycle. The application of cooperative learning with the Student Team Achievement Division (STAD) type can improve the learning activities of Class V students at SDN 15 Cakranegara in the 2018 - 2019 academic year for social studies subjects. This is indicated by the percentage in each observed aspect which increases from cycle I to cycle II. Based on the results of observations, the percentage of student activity in the first cycle is $65 \%$. This percentage increased in cycle II to $81 \%$. Based on the results of observations of teacher activities in the learning process, the results showed that there was an increase in teacher activity in carrying out learning by implementing cooperative learning type Student Team Achievement Division (STAD) from $75 \%$ in the first cycle to $87 \%$ in the second cycle. 


\section{REFERENCES}

Arikunto, S. (2012). Prosedur Penelitian : Suatu Pendekatan Praktik (Edisi Revisi).

Fatimah, F. N. (2021). Peningkatan Hasil Belajar Siswa pada Materi Bagian Tumbuhan melalui Metode STAD di Kelas IV SDN 1 Joho Kecamatan Pace Kabupaten Nganjuk. PTK: Jurnal Tindakan Kelas, 2(1), $62-67$. doi:10.53624/ptk.v2i1.44

Jufri, A. W. (2010). PENELITIAN TINDAKAN KELAS: ANTARA TEORI DAN PRAKTEK. JURNAL PIJAR MIPA, 5(2). doi:10.29303/jpm.v5i2.166

Nurdin, S. (2016). Guru Profesional dan Penelitian Tindakan Kelas. Jurnal Educative : Journal of Educational Studies, 1(1). doi:10.30983/educative.v1i1.118

Prastya, D. (2017). PENINGKATAN HASIL BELAJAR IPA MELALUI PENERAPAN MODEL PEMBELAJARAN COOPERATIVE TIPE STUDENT TEAMS ACHIEVEMENT DIVISION (STAD) PADA SISWA KELAS V SEKOLAH DASAR. EduHumaniora - Jurnal Pendidikan Dasar Kampus Cibiru, 9(2), 99. doi:10.17509/eh.v9i2.7079

Rahmah, R. A., Fakhriyah, F., \& Fardani, M. A. (2020). The Influence Of Stad Model Assisted With Alpin Media Towards The Understanding Of Students' Concepts Theme 6 Grade IV. Jurnal Ilmiah Sekolah Dasar, 4(3), 388. doi:10.23887/jisd.v4i3.27728

Sumilat, J. M., \& Matutu, V. S. (2021). Model Pembelajaran Kooperatif Tipe STAD (Student Teams Achievement Divisions) Untuk Meningkatkan Hasil Belajar Sisiwa Sekolah Dasar. EDUKATIF : JURNAL ILMU PENDIDIKAN, 3(3), 865-870. doi:10.31004/edukatif.v3i3.392

Wicaksono, A. A., \& Bariska, H. F. (2018). PENERAPAN MODEL PEMBELAJARAN KOOPERATIF TIPE STAD UNTUK MENINGKATKAN HASIL BELAJAR SISWA PADA MATA PELAJARAN IPS SISWA KELAS V SD MATERI KERAJAAN DAN PENINGGALAN HINDU DI INDONESIA. Inteligensi : Jurnal Ilmu Pendidikan, 1(1), 31-38. doi:10.33366/ilg.v1i1.1141

Widayati, A. (2014). PENELITIAN TINDAKAN KELAS. Jurnal Pendidikan Akuntansi Indonesia, 6(1). doi:10. 21831/jpai.v6i1.1793

Winaastari, N. P. A., Yudiana, K., \& Kusmariyatni, N. N. (2020). Model Pembelajaran STAD Berorientasi THK Meningkatkan Kompetensi Pengetahuan IPA Siswa Kelas V Sekolah Dasar. Jurnal Pedagogi dan Pembelajaran, 3(2), 280. doi:10.23887/jp2.v3i2.26617

Zahro, F., Degeng, I. N. S., \& Mudiono, A. (2018). Pengaruh model pembelajaran student team achievement devision (STAD) dan mind mapping terhadap hasil belajar siswa kelas IV sekolah dasar. Premiere Educandum : Jurnal Pendidikan Dasar dan Pembelajaran, 8(2), 196. doi:10.25273/pe.v8i2.3021 